\title{
The State and the Rural Economy in the People's Republic of China
}

\author{
Jack Gray
}

$I$

The 'state' in China needs definition. China, like all other communist countries, is governed not through institutions legitimised by the state constitution, but by a single party which can dictate to state organs. Thus the retreat of the state in certain fields need not be paralleled by a retreat of the party and may even be accompanied by an increase in party, as opposed to state, control, as during the Great Leap Forward. And while the state apparatus, if it is to function, must adopt rules which limit its actions, the party is under no such self-limitation. When it takes over the functions of the state it can behave in much more arbitrary ways

Communist parties indeed emphasise that they are above the law; the law serves the revolution and the party guides the revolution. This attitude has been strengthened by China's own traditional hostility to codified law. As a result, in China even more than in the European communist countries, party policy statements frequently serve in place of law, and many fundamental rights are not legally defined.

The party is only the greatest of China's quasi-state organisations. In the economic field, in addition to state trading organs and state banks, the rural supplyand-marketing and credit cooperatives, although formally not part of the state apparatus, have hitherto functioned entirely as if they were. In fact in 1977 the supply-and-marketing cooperatives were formally made state organs. Most important of all, the agricultural collectives themselves (as in other communist countries), although in theory they are cooperatives voluntarily created and self-governing, have been operated as if they were state enterprises with the notable difference that they are responsible for their own losses.

It is through these parastatal organisations that the state is in touch with the rural population. The communes have been especially ambiguous; for while in respect of their economic functions they were ostensibly cooperatives, as political and administrative bodies they almost immediately came to represent a new and lower level of state bureaucracy, with their theoretically elected functionaries on the state pay roll. In this way, for the first time in Chinese history the state apparatus penetrated the villages. Even the lower level of cooperative organisation, the production brigade, was in a similarly ambiguous position. Its primary function was to ensure the fulfilment of the state plan; little in the way of resources remained for activities not dictated from above. It was told not only what to plant but when.

\section{II}

This assimilation of all decision-making power by the party hierarchy has been common to all Sovietderived socialism; in fact, such dictatorial control was made necessary by certain policy assumptions from which Soviet collectivisation began..There were three such assumptions: first, that the large-scale mechanised farming of the United States was the most efficient in all circumstances; second, that capital for industrialisation could only be raised, as (it was wrongly believed) it had been raised in Britain's industrial revolution, by a process of 'primitive accumulation' at the expense of the peasants; and third, that the collective organisation of farm labour, as opposed to the infrastructure of farming, had some sort of intrinsic 'socialist' moral value. None of these assumptions is self-evident, to say the least.

However, if agricultural policy is to be based on expropriating peasants to force them into large-scale farming, squeezing their incomes to pay for industrialisation, and subjecting them to a collective labour discipline which may actually be counterproductive, then dictatorship must follow. The authoritarian system once established creates its own vested interests, which are then rationalised in the insistence that the original dubious policy assumptions are part of ideology. The economic and political systems thus become mutually supporting. 
The first attempt made by the Chinese Communist Party to break out of the application to agriculture of centralised economic command, and to create an alternative to Stalinist agriculture, was in the form of the Great Leap Forward and the commune system. The rationale of these revolutionary changes, as far as Mao himself is concerned, can be summed up as follows:

Mao condemned Soviet squeezing of agriculture to finance industrialisation. He condemned the idea that the development of heavy industry must have absolute priority in investment, and insisted that agriculture must come first, then light industry, believing that the increase of peasant purchasing power was the real key to development. He accused Stalin of neglecting individual incentives and overstressing collective incentives. He accused him of having eliminated the masses from economic decision-making. He repudiated Stalin's insistence that socialist society is without conflict, argued that conflict was the necessary motive force of change and accepted that there were conflicts of interest between state and collective and between collective and individual. He argued that in China's economic conditions the market must play a greater role than in the Soviet Union and that producers' goods as well as consumers' goods must be bought and sold rather than allocated. He insisted on the importance of the diversification of agriculture and of the rural economy, and he saw the development of rural industries as the main means of accumulating the capital necessary to transform agriculture. He was the first to see that the original large-scale commune of 1958, which brought rich and poor villages into a single unit of account and distribution, was unacceptable to the more prosperous villages; hence the creation of the three-level system with the small production team as the main unit of ownership. He roundly condemned the coercive allocation of peasant resources by county and commune cadres in the Great Leap, and defended peasant resistance to this 'banditry'. He insisted that agricultural planning should be indicative, not authoritative, so that grass-roots economic decision-making would become a reality. He asked for, but never got, proper and regular election of commune, brigade and team cadres.

[Feuchtwang and Hussain 1983: 154-5]

In adjusting intersectoral priorities, however, Mao's intention was not to make drastic changes in the allocation of central investment funds between heavy industry and agriculture: first, because the central budget in China represents only one level of investment, and investment in agriculture increases as a proportion of the total as one moves down to province and thence to the county (xian); second, because Chinese agriculture in 1958 had not reached the stage at which it could absorb massive increases in state investment; third, because Mao believed that it would be more efficient, as well as less bureaucratic, to make it possible for the rural communities to save and invest for themselves out of their (putatively) increasing incomes by keeping land tax and procurement norms sufficiently low to leave room for local accumulation, and then to enhance this possibility through the development of local collective industries and other enterprises. Conversely, statesector industry was expected to respond to the demands created by rural industrialisation. These ideas were the basis of the Great Leap Forward and the communes of 1958 .

The Great Leap and the communes were a tragic failure, economically disastrous and politically intolerable; but the reason for failure did not lie in the economic ideas of the Leap - the use of rural surplus labour to develop rural infrastructure and village industries. The reasons for failure were political. Given the existence of the authoritarian party/state st ructure, the new opportunities for local community decision-making and enterprise were pre-empted by the authorities. Ironically, the command economy was thrust right down to the village level, where peasant property and resources were allocated by the cadres as if they were the property of the state.

The irony extended to most of the individual features of the commune/Great Leap system [Brugger 1977:149ff]. In the attempt to give the villages the means to develop agriculture and light industry for themselves, they were induced to try to concentrate on small-scale heavy industries, especially iron and steel making, and through this attempt Stalin's priority to heavy industry was reasserted in the very village itself, in wasteful and irrational forms symbolised by the 'backyard blast furnace'. In the attempt at rapid development of village industries, a higher rate of squeeze than ever was imposed on agriculture for local investment. In the overstrained drive to transform rural China in three years, individual material incentives, whose importance Mao had declared that Stalin neglected, were almost totally eliminated. The conflict of interest between state and collective and between collective and individual, which Mao had stressed as both inevitable and creative, was totally ignored. The market dimension of the rural sector shrank instead of growing. The obsession with grain monoculture grew to new heights and prevented the diversification of production which was fundamental to the Great Leap strategy. The commune, in theory a higher form of democratic, self-managing collective, became a new state instrument. Agricultural planning, so far from becoming indicative, became more authoritarian than ever. The whole process, the major 


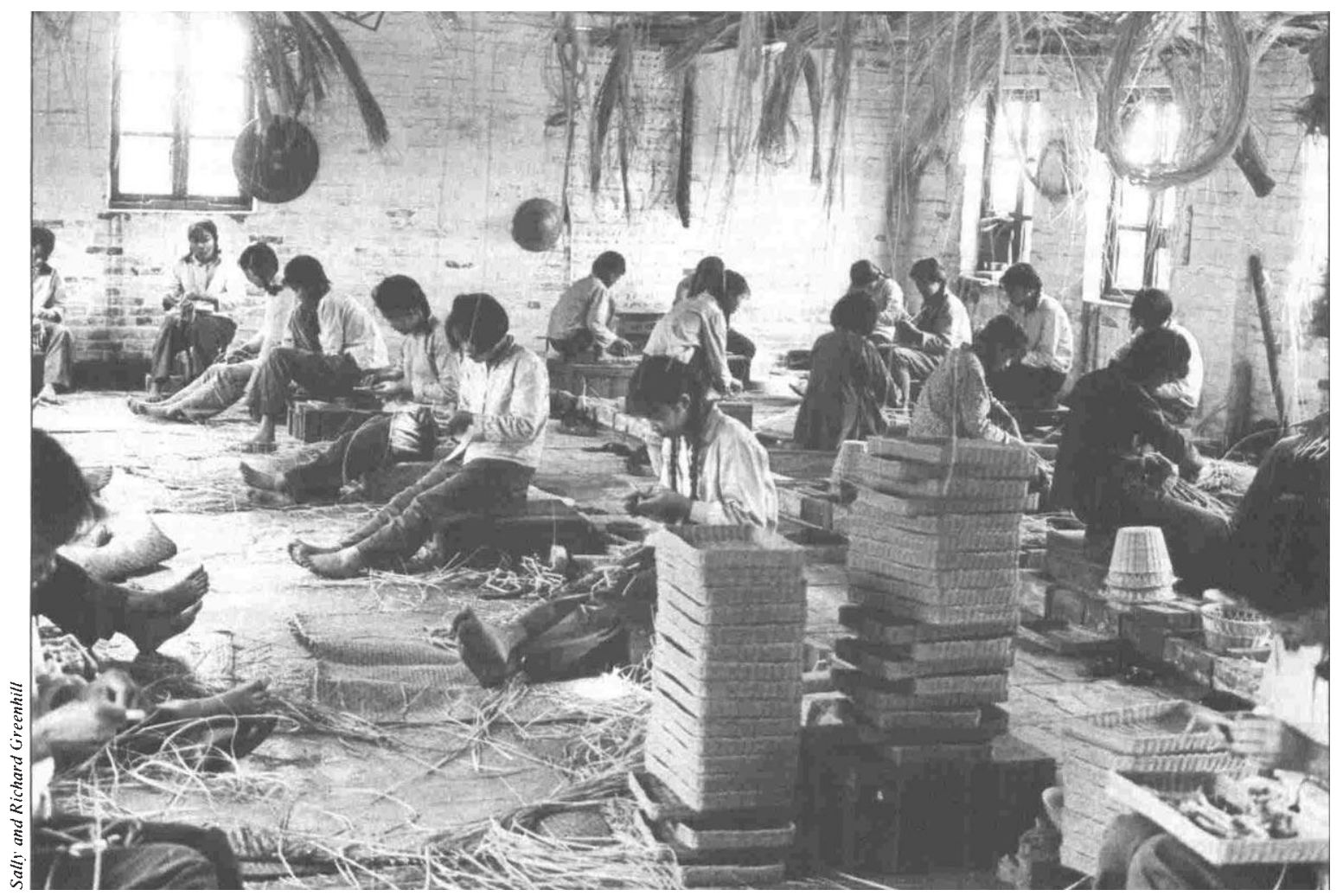

Handicrafts in a Chinese commune.

premise of which had been the necessity for local democratic economic decision-making as the source of new consciousness and new motivation, turned into an exercise in commandism paralleled only by the Soviet collectivisation drive.

The most striking distortion of the original policies of the Great Leap was the fact that the newly established communes, which were intended to be superior collectives, were merged with the local political administration. Their leaders being state employees, the state paid the piper and therefore called the tune, and the commune became little more than a transmission belt for conveying government orders to the villages.

There is another aspect of the theory of the communes which added to the confusion. The Chinese name gongshe is not an old Chinese word. It was invented to refer specifically to the Paris Commune of 1871 . The ideological implications of its use in 1958 are obvious, and are of great importance for Chinese theories of the state.

The theme of the first book on socialism which the young Mao Zedong read, Kirkup's History of
Socialism, was precisely the contradiction in socialist minds between étatisme and communalism, between Saint Simon and Robert Owen, a contradiction which Marx and Engels left unresolved. Mao was on the side of Owen; in fact, if the characteristics of an Owenite community listed in Kirkup's book are compared with the original characteristics of the Chinese commune, the parallel is extraordinary. From the beginning, the commune was regarded therefore not simply as a new tier of economic organisation, but as a new form of community, a substitute for 'bourgeois state' institutions. But this did not prevent it from being assimilated to the existing Chinese state, against which it could bring no countervailing power.

\section{III}

In the reaction which followed the collapse of the Leap, when most of the new village industries were condemned and closed down, and when the great labour-intensive water conservancy schemes of 195859 had been discredited, the commune actually lost in practice most of the economic functions it had first been designed to fulfil; it became more than ever simply the lowest rung in the hierarchy of state 
territorial administration. Had this been the whole story, the results might have been better. But the presumption was retained that the commune had the right and the duty to raise revenue from its members for economic development, ostensibly by democratic decision, but in fact largely on orders from the xian government.

In the interval between the end of the Leap in 1960 and the Cultural Revolution, the Liu Shaoqi regime reverted to the norms of state socialism, but with modifications broadly similar to those which were being attempted in Eastern Europe and to a certain extent in the Soviet Union itself. As far as agriculture is concerned, the unit of cultivation and of distribution of income was reduced from commune to production brigade and then to the production team of 30 or 40 families. A larger private sector of agriculture was permitted, with increased private plots and more freedom for rural fairs. Indeed in the desperate circumstances which succeeded the Leap and the adverse weather conditions of 1960 and 1961 which exacerbated the problems of agriculture, in some places the party even tolerated a regression to private farming and private land reclamation. At the same time the new village industries, centre and symbol of Maoist rural policy, were for the most part abolished as inefficient and wasteful, while agricultural mechanisation and the ownership and operation of agricultural machinery was resumed by the state.

Mao condemned the new policies as 'revisionist'. In his analysis of revisionism, he saw Stalin (paradoxically) as its author [Joint Publications Research Service 1974:129]. Stalin's system prevented popular participation; mass management gave way to coercion. Khrushchev partially substituted the carrot for the stick, but nothing else changed. Popular participation remained minimal. Liu Shaoqi seemed to be prepared to accept the same in China, and even to encourage it. The result, to $\mathrm{Mao}$, was the creation of a new 'red bourgeoisie'.

The left-wing alternative was to restore Great Leap decentralisation. But there were changes. First, the writers and educators who had led the public condemnation of the Great Leap in the early $1960 \mathrm{~s}$ had to be countered. Second, the political leaders who were content to operate the state-socialist system must be made to see the error of their ways. Third, and most important, the party cadres whose arbitrary power had distorted the Great Leap must be put under the supervision of the masses.

For some months in late 1966 it looked as if the party, and perhaps even the state as it existed, would disappear when Shanghai set up a Paris-Commune government. This was accompanied by 'seizures of power' in enterprises, ministries and institutions of all kinds, in order to destroy hierarchical authority and replace it with mass management.

Mao, however, drew back from the brink and refused to approve of the Shanghai Commune. He preferred the creation of 'revolutionary committees' in which representatives of the left wing, soldiers and reconstructed party cadres were associated.

The Great Leap process was nevertheless begun again. In particular, commune industries grew rapidly until they became an essential part of the rural economy.

Since the death of Mao in September 1976 and the arrest of the Gang of Four, rural policies associated with the left have been subjected to trenchant criticism [BBC, Summary of World Broadcasts; US, Foreign Broadcast Information Service]. First, it is asserted that left-wing control has in the past been associated with low levels of growth in agriculture. Grain output in 1960 after the failure of the Leap was less than in 1951. From 1962 to 1965 , when right-wing policies were applied, annual growth soared to 6.7 per cent per annum. When the left again took over it sank to 4.5 per cent.

The concentration on self-sufficiency in grain not only limited supplies of other products but deprived peasants of other possible sources of earnings and so depressed both incomes and savings. It also damaged the ecology.

Massively increased local investment in agriculture gave only poor returns. While farm costs rose between 1965 and 1977 by 130 per cent, production rose only 80 per cent, and in many places peasant incomes actually fell although production increased.

The burdens on the peasants were increasingly heavy. On average about 30 per cent of gross production was deducted, including the collectives' own accumulation for investment and welfare, before distribution of the product, a figure not ver y different from the burden of rent before the revolution. This was the result of uncontrolled investment, the absence of accounting and the swollen numbers of cadres drawing high salaries.

There was much arbitrary reallocation of peasant resources: 'in violation of exchange at equal value some state organs, enterprises, departments and units transfer the resources of teams and appropriate labour, grain, funds and materials' [Foreign Broadcast Information Service, 253/L42, 1980]. Every attempt to create a system of rational rewards for farm labour had failed because "for most of the year farm tasks cannot be expressed in terms of output' [Foreign Broadcast Information Service, 044/Q1, 1981]. The 
result of all this was an absence of incentives to work. 'Who wants to do unprofitable labour?' said the peasants. 'The women made sandals, the men loafed ...' [Foreign Broadcast Information Service, 238/W2, 1981]. At the same time productivity on the private plot was much higher than on the collective fields.

This indictment of the rural policies of the culturalrevolution leaders by their successors must be treated with some caution. Chinese agriculture certainly did suffer from all these disadvantages and difficulties, but their extent and their severity are not known. They did not all originate from the cultural revolution, and they did not prevent a steady rise in agricultural production (said to be 4.5 per cent per annum) quite comparable to that which had occurred from 1962 to 1965, when one allows for the fact that the much higher rate of growth now claimed for these years $(6.7$ per cent) partly represented a recovery from the near-famine conditions of 1959-61.

\section{IV}

In the past the state, or the party replacing the state, or in the cultural revolution the insurgent revolutionary committees replacing the party, have exercised great authority over village production. Under all these various dispensations, whatever the differences in their theoretical aims, the command economy has commanded right down to the grass roots. The resources and the energies of the village have been almost wholly absorbed in fulfilling detailed plans imposed from above. Production has been organised under the direct management of the team or brigade leaders.

Deng Xiaoping's answer is the contract. Its use enables state authority to retreat from production and to leave the producers, collective or individual, to employ their resources as they think best to meet their contractual obligations; having done so, they can use their surplus resources in whatever way - subject to certain constraints of public policy - is most profitable.

Whether Deng's contract system will work as intended depends of course on the nature of the contract. To reach its aims, it must be such as to leave the contractor with some resources to spare after meeting his obligations, and it must be enforceable in the courts on the basis of a system of law of contract. So far neither of these criteria has been completely met. Local cadres who are hostile to the new policies can, and frequently do, force contract stipulations so high as virtually to perpetuate the old system. Contract law, though emphatically promised, has not yet appeared. The system still operates only on party policy as locally enforced. It may be added that in the absence of firm contract law tested by the courts there is also little guarantee that the contract system will not operate cumulatively to the advantage of a more prosperous minority.

The advantages of this system, according to its creators, are numerous. Individual incentives are maximised, but planning retained. Management of farming by the cadres, whose competence to manage is in doubt, is minimised. Responsibilities are clearly defined. Accounting is simplified. Specialised division of labour is made possible.

Commune and brigade enterprises are now also being handled in the same way as agriculture. Hitherto they were managed as branches of the collective. They now contract to transmit a fixed amount of profit to the collective, retaining the rest for investment and bonus distribution. They have in effect (though not in law) ceased to be owned by the collective and are owned instead by their workers.

The flexibility of this system is such that the commune structure inherited from the Great Leap is no longer seen to be of importance, and its vices have come to loom larger than its virtues [Foreign Broadcast Information Service, 048/L2, 1981 ; Guangming Ribao, 6 November 1979]. Its amirable internal flexibility in allowing different tasks to be undertaken at three different levels of collective organisation, its capacity to mobilise local resources, and its potential to respond politically to the economic and social needs of its members seemed to its critics to have been negated by centralised state-party control which in practice made it extremely inflexible and unresponsive. Again the criticisms seem to be valid, but at the same time much exaggerated. However, since 1981 in fact preparations have been under way to abolish it. The first and simplest change is to remove from the commune the political authority which it has enjoyed, while retaining its economic functions. Hitherto, however, the commune has carried out its economic functions largely by the use of its political authority. With that authority removed, it needs a new relationship with lower-level institutions. The most common of the experimental solutions so far has been to reconstitute it as an agricultural-industrialcommercial trust' whose constituent firms are the agricultural teams and the commune and brigade industries. As an enterprise, it is responsible for its own profits and losses.

These changes, when they are applied throughout China, will represent a vast process of privatisation. It is, however, socialist privatisation, for the unit of ownership is still the collective.

The changes have been made possible by the repudiation in China of the three policy assumptions concerning socialist agriculture which were recalled at 
the beginning of this article. Mao Zedong began the attack on them by repudiating the theory of pimitive accumulation and insisting that increasing peasant purchasing power was the real motive force of Chinese development.

However, under Mao the other two shibboleths belief in the economies of scale of collective agriculture and in the moral necessity of collective production - remained unquestioned. Now they too have been repudiated. It is recognised that in the present conditions of Chinese agiculture family-scale farming is still the most efficient for most purposes and in most places. It is also asserted that the question of the organisation of day-to-day production is not a question of ideological principle but simply of practical efficiency.

Contract is a phenomenon of the market, and its use in China is part of a process of relaxing central planning in favour of market relations. By 1982, 80 per cent of the produce of commune and brigade enterprises was outside the plan, while agriculture is now (in theory at least) subjected only to indicative planning backed by price and taxation policies. This, however, is misleading if it suggests the dominance of free markets. These are still marginal. The purchasers of rural produce are mainly monopsonistic state trading organs, parastatal supply-and-marketing cooperatives, state department stores in the cities, state sector industrial enterprises and the foreign trade commission. They buy on contract. The prices are fixed, and competition is confined to quality and design.

The new agricultural system could be largely nullified if the contracts awarded to peasant families and work groups were tightened up, so that all their available resources were employed in meeting their obligations. This is not merely theoretical; it is the normal way in which local leaders who are hostile to the new system try to beat it.

This brings us to the question of the protection of the rights and interests of rural producers. There has been enormous emphasis on this [Foreign Broadcast Information Service, 118/K9, 1981], but so far legislation, although promised, has not been published and protection still depends on party documents. This has three dangers. First, party policy may change, as Chinese peasants know. Second, local party cadres can often interpret policy to suit themselves. Third, redress for wrongs must generally be sought from the party, not in the courts, and party cadres have means of retaliating against their accusers. Until there is adequate law on contracts and on the requisition of labour and other resources from the production teams and the collective enterprises, the new developments could be reversed at will.
Finally, let us look at the changes in China in a wider perspective. Do they express, implicitly at least, a new theory of the socialist state?

It is possible that the relinquishment of the 'three shibboleths' in China has now made authoritarian control of agriculture unnecessary. If this is so, the relations between the state and rural society may well move in a direction more consonant with China's own political traditions.

At a central committee meeting Mao once defined the role of the state/party leadership as follows: 'Our job is to produce ideas and employ cadres'. Now that is not a definition of government which would ever have entered the head of a western statesman, communist or non-communist. It is absolutely Chinese; mutatis mutandis, the Kang Xi Emperor would have been quite happy with it. We can be sure that Mao's audience automatically responded by locating his definition on the familiar Chinese spectrum that runs from Legalist maximal government to Taoist minimal government. We can also be sure that those who, like Mao, had read Kirkup in their youth would have assimilated the Legalist-Taoist dichotomy to that of state socialism versus communalist socialism. And we can be sure that many responded positively when Mao thus unconsciously reaffirmed traditional expectations concerning the role of government.

When we look back on the history of Chinese twentieth century radicalism generally, what is most striking about it is the bias towards communalism, narodnism, anarchism. Chinese radical prescriptions for development were concerned with the self-renewal of the village, in which the state was expected to act as a catalyst to stimulate mass consciousness. The activity of the government was not expected to preempt local initiative, only to encourage, guide and protect it.

In these respects Mao was in the mainstream of Chinese radical thought. In one sense he was also still in the mainstream of traditional government. In imperial China the relation between government authority and social institutions was summed up in such phrases as 'government supervision, popular management', 'central supervision, local management', 'official supervision, merchant management' and other similar formulae. Mao Zedong defined the system of the wartime Border Region in the same terms: 'central supervision, local management'. In 1958 , via the commune system, he sought to reassert this concept, but without real success. Now in the abolition of the commune, Deng Xiaoping aims to get rid of it as having become a bureaucratic obstacle to 
the realisation of this traditionally sanctioned relationship between state and society.

It is thus possible that the Chinese are returning, albeit unconseiously, to their own traditions of government, as far as relations with rural China are concerned. If so, one should bear in mind, however, that China's imperial governments were seldom able to resist in practice the temptation to turn the governmentsupervised voluntary associations into new organs of surveillance and control. The tradition is doubleedged.

\section{References}

BBC, Summary of World Broadcasts, Part 111, the Far East:
1980-6427/BII/1, 6437/B11/5, 6479/B11/1, 6568/B1I/5; $1981-6814 / \mathrm{B} 11 / 1,6826 / \mathrm{C} / 3,6843 / \mathrm{B} 11 / 2$.

Brugger, W., 1977, Contemporary China, Croom Helm, London

Feuchtwang, S. and A. Hussain (eds), 1983, The Chinese Economic Reforms, Croom Helm, London

Joint Publications Research Service, 1974, Miscellany of Mao Thought, Arlington, Virginia

US, Foreign Broadcast Information Service, Daily Report, China:

$1980-101 / \mathrm{L} 11,253 / \mathrm{L} 42 ; 1981-238 / \mathrm{W} 2,145 / \mathrm{T} 1$, 174/K7, 044/Q1. 